\title{
Roseovarius indicus sp. nov., isolated from deep-sea water of the Indian Ocean
}

\author{
Correspondence \\ Zongze Shao \\ shaozz@163.com \\ Tianling Zheng \\ wshwzh@xmu.edu.cn
}

\author{
Qiliang Lai, ${ }^{1,2}$ † Huanzi Zhong, ${ }^{1,2}$ † Jianning Wang, ${ }^{2}$ Jun Yuan, ${ }^{3}$ \\ Fengqin Sun, ${ }^{2}$ Liping Wang, ${ }^{2}$ Tianling Zheng ${ }^{1}$ and Zongze Shao ${ }^{2}$
}

\author{
${ }^{1}$ MOE of Key Lab for Coast and Wetland Ecosystem, School of Life Sciences, Xiamen University, \\ Xiamen 361005, PR China \\ ${ }^{2}$ Key Laboratory of Marine Biogenetic Resources, Third Institute of Oceanography, State Oceanic \\ Administration, Xiamen, PR China \\ ${ }^{3}$ College of Life Science, Fujian Agriculture and Forestry University, Fuzhou, PR China
}

In a study investigating polycyclic aromatic hydrocarbon (PAH)-degrading bacteria in deep-sea water of the Indian Ocean, many bacterial strains were isolated and characterized taxonomically. One of these isolates, designated strain $\mathrm{B} 108^{\mathrm{T}}$, was chosen for further investigation. Comparative $16 \mathrm{~S}$ rRNA gene sequence analysis indicated that strain $\mathrm{B} 108^{\mathrm{T}}$ formed a clade with the genus Roseovarius within the family Rhodobacteraceae. The genus Roseovarius was

†These authors contributed equally to this work.

Abbreviation: $\mathrm{PAH}$, polycyclic aromatic hydrocarbon.

The GenBank/EMBL/DDBJ accession number for the 16S rRNA gene sequence of strain $B 108^{\top}$ is EU742628.

Three supplementary figures and a supplementary table are available with the online version of this paper. proposed by Labrenz et al. (1999) and, at the time of writing, included eight type strains: Roseovarius tolerans (Labrenz et al., 1999), Roseovarius nubinhibens (González et al., 2003), Roseovarius crassostreae (Boettcher et al., 2005), Roseovarius mucosus (Biebl et al., 2005), Roseovarius aestuarii (Yoon et al., 2008), Roseovarius pacificus (Wang et al., 2009), Roseovarius halotolerans (Oh et al., 2009) and Roseovarius nanhaiticus (Wang et al., 2010). Strain $\mathrm{B} 108^{\mathrm{T}}$ was characterized by using a polyphasic taxonomic approach including the determination of phenotypic properties and a detailed phylogenetic analysis based on $16 \mathrm{~S}$ rRNA gene sequences.

Deep-sea water was sampled from a depth of $4696 \mathrm{~m}(50 \mathrm{~m}$ above the sea floor) at the site of IR-CTD5-2 $\left(31.0710^{\circ} \mathrm{S}\right.$ $58.9945^{\circ}$ E) on the South-west Indian Ridge during the 
cruise of DY-105A of R/V 'Da-Yang Yi-Hao' in December 2005. The sample was enriched with PAHs (100 p.p.m. phenanthrene, 10 p.p.m. anthracene, 10 p.p.m. fluorantheneand 10 p.p.m. pyrene) and the strains were isolated on 216L marine agar medium, comprising (g per 1 seawater) $\mathrm{CH}_{3} \mathrm{COONa}$ (1.0), Tryptone (10.0), yeast extract (2.0), sodium citrate (0.5), $\mathrm{NH}_{4} \mathrm{NO}_{3}(0.2)$ and agar (15) ( $\left.\mathrm{pH} 7.5\right)$, following the method described by Lai et al. (2010). For morphological and biochemical characterization, strain $\mathrm{B}_{108^{\mathrm{T}}}$ was cultivated on marine agar (MA) 2216 medium (BD).

Genomic DNA was prepared according to the method of Ausubel et al. (1995) and the 16S rRNA gene was amplified by PCR using primers that had been described previously (Liu \& Shao, 2005). Sequences of related taxa were obtained from the GenBank database. Phylogenetic analysis was performed using MEGA version 4 (Tamura et al., 2007) after multiple alignment of data by DNAMAN (version 5.1; Lynnon Biosoft). Distances (distance options according to the Kimura two-parameter model) and clustering with the neighbour-joining (Saitou \& Nei, 1987), maximumparsimony and minimum-evolution (Rzhetsky \& Nei, 1992, 1993) methods were determined by using bootstrap calculations based on 1000 replications.

The nearly full-length 16S rRNA gene sequence (1430 nt) of strain $\mathrm{B} 108^{\mathrm{T}}$ was determined. Phylogenetic analysis of strain $\mathrm{B} 108^{\mathrm{T}}$ indicated that it belonged to the class Alphaproteobacteria, forming a robust clade within the genus Roseovarius in the neighbour-joining tree (Fig. 1). The resultant maximum-parsimony tree is shown in Supplementary Fig. S1, available in IJSEM Online. Strain B108 formed a group with $R$. halotolerans $\mathrm{H} 550^{\mathrm{T}}$ and $R$. pacificus $81-2^{\mathrm{T}}$ in both trees. The closest related species was R. halotolerans $\mathrm{HJ}_{50} 0^{\mathrm{T}}$ (97.1\% 16S rRNA sequence similarity), followed by R. pacificus $81-2^{\mathrm{T}}(96.6 \%)$ and $R$. aestuarii SMK- $122^{\mathrm{T}}$ (95.2\%); other species shared $<95.0 \%$ sequence similarity. In general, a $16 \mathrm{~S}$ rRNA gene sequence divergence
$>2 \%$ is accepted as the recommended criterion for delineating different species (Stackebrandt \& Goebel, 1994). 16S rRNA gene sequence divergences between strain $\mathrm{B} 108^{\mathrm{T}}$ and recognized species of genus Roseovarius were $\geqslant 2.9 \%$, and thus the data supported the view that strain $\mathrm{B} 108^{\mathrm{T}}$ represented a novel species. The signature nucleotides detected for strain $\mathrm{B} 108^{\mathrm{T}}$ were: helical region $240-242 / 284-$ 286 UAG/CUA, position 113-115/312-314 GUG/CAC and position 577-580/764-767 GCGC/GUGC.

DNA-DNA hybridization experiments were performed as previously described (Liu \& Shao, 2005) with genomic DNA of strain $\mathrm{B} 108^{\mathrm{T}}, R$. halotolerans $\mathrm{HJ} 50^{\mathrm{T}}$ and $R$. pacificus $81-2^{\mathrm{T}}$. Strain $\mathrm{B} 108^{\mathrm{T}}$ showed low DNA-DNA relatedness to R. halotolerans $\mathrm{HJ} 50^{\mathrm{T}}$ and R. pacificus $81-2^{\mathrm{T}}(48 \pm 4 \%$ and $44 \pm 5 \%$, respectively), demonstrating its affiliation to a novel species in accordance with the cut-off value of $70 \%$ recognized by Wayne et al. (1987) for the discrimination of bacterial species.

Gram reaction, activities of catalase, oxidase and lipase (Tween 80), hydrolysis of aesculin and starch, optimal temperature and $\mathrm{pH}$ for growth, tolerance to $\mathrm{NaCl}$, antibiotic susceptibility and general cell morphology via electron microscopy were determined as described previously (Lai et al., 2010). Other biochemical tests were carried out on API 20 NE and API ZYM strips (bioMérieux) according to the manufacturer's instructions but with media adjusted to contain $3 \%(\mathrm{w} / \mathrm{v}) \mathrm{NaCl}$. The results are given in the species description and in Table 1. Eight type species of the genus Roseovarius were, in most cases, tested in parallel for comparison (Table 1).

The G+C content of the chromosomal DNA was determined according to the methods described by Mesbah \& Whitman (1989) using reversed-phase HPLC. The DNA $\mathrm{G}+\mathrm{C}$ content of strain $\mathrm{B} 108^{\mathrm{T}}$ was $63.6 \mathrm{~mol} \%$, which was in the range previously reported for species of the genus Roseovarius (58.6-66.0 mol\%).

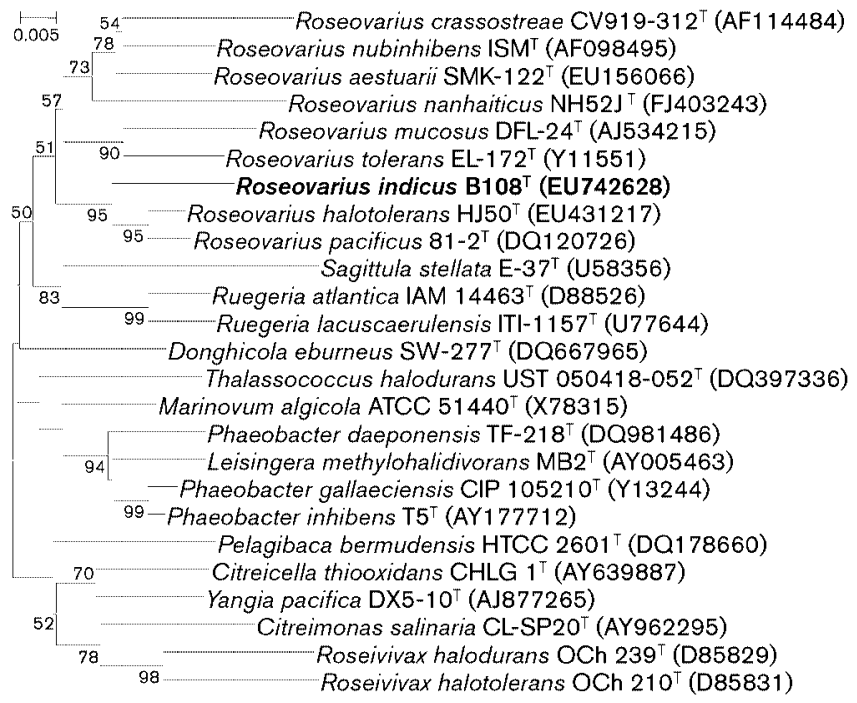

Fig. 1. Neighbour-joining tree showing the phylogenetic positions of strain $\mathrm{B}_{108^{\top}}$ and representatives of related taxa, based on $16 \mathrm{~S}$ rRNA gene sequences. Bootstrap values (expressed as percentages of 1000 replications) are shown at branch points. Bar, 0.005 substitutions per nucleotide position $\left(K_{\text {nuc }}\right)$. 
Table 1. Characteristics that differentiate $B 108^{\top}$ from related species of the genus Roseovarius

Strains: $1, \mathrm{~B} 108^{\mathrm{T}}$ (results from this study); 2, R. halotolerans $\mathrm{HJ} 50^{\mathrm{T}}$ (Oh et al., 2009); 3, R. pacificus 81-2 ${ }^{\mathrm{T}}$ (Wang et al., 2009); 4, R. aestuarii SMK-122 $2^{\mathrm{T}}$ (Yoon et al., 2008); 5, R. nubinhibens DSM $15170^{\mathrm{T}}$ (González et al., 2003); 6, R. tolerans EL-172 ${ }^{\mathrm{T}}$ (Labrenz et al., 1999); 7, R. nanhaiticus NH52J ${ }^{\mathrm{T}}$ (Wang et al., 2010); 8, R. mucosus DFL-24 ${ }^{\mathrm{T}}$ (Biebl et al., 2005); 9, R. crassostreae DSM 16950 ${ }^{\mathrm{T}}$ (Boettcher et al., 2005). Catalase, oxidase, API 20 NE and API ZYM tests were performed for all type strains at the same time. All strains were positive for catalase and oxidase activities. In the API $20 \mathrm{NE}$ system, all strains were negative for indole production, D-glucose fermentation, $\beta$-glucosidase, gelatin hydrolysis, $\beta$-galactosidase activity and utilization of adipic acid, capric acid, D-glucose, maltose, D-mannitol, D-mannose, L-arabinose, malic acid, $N$-acetylglucosamine, phenylacetic acid, potassium gluconate and trisodium citrate. In the API ZYM system, all strains were positive for alkaline phosphatase, esterase (C4) and leucine aminopeptidase activities but were negative for $N$-acetyl- $\beta$-glucosaminidase, trypsin, $\alpha$-chymotrypsin, $\alpha$-fucosidase, $\alpha$-and $\beta$-galactosidase, $\alpha$ - and $\beta$-glucosidase, $\alpha$-mannosidase and $\beta$-glucuronidase. All strains were sensitive to carbenicillin, gentamicin and penicillin $\mathrm{G}$ but resistant to lincomycin, polymyxin B and tetracycline.

\begin{tabular}{|c|c|c|c|c|c|c|c|c|c|}
\hline Characteristic & $1^{*}$ & 2 & 3 & 4 & 5 & 6 & 7 & 8 & 9 \\
\hline Motility & - & - & + & + & + & + & + & & + \\
\hline Flagella & - & - & Subpolar & Polar & ND & - & - & - & Subpolar-lateral \\
\hline Tolerance of $\mathrm{NaCl}(\%, \mathrm{w} / \mathrm{v})$ & $1-15$ & $0.5-20$ & $1-15$ & $\leqslant 7$ & $0.8-4.7$ & $1-15$ & $0.5-10$ & $0.3-10$ & ND \\
\hline Optimal salinity (\%) & $3-5$ & $3-4$ & $2-12$ & ND & $1.1-2.3$ & $1-8$ & $2-4$ & $1-7$ & $1-1.5$ \\
\hline Temperature range for growth $\left({ }^{\circ} \mathrm{C}\right)$ & $10-39$ & $10-45$ & ND & $10-37$ & $10-40$ & $3.0-43.5$ & ND & $20-40$ & $19-40$ \\
\hline Optimum temperature $\left({ }^{\circ} \mathrm{C}\right)$ & 25 & 35 & 25 & 30 & 30 & $8.5-33.5$ & 30 & 31 & 34 \\
\hline $\begin{array}{l}\text { Photosynthetic reaction centre genes } \\
\qquad(\text { pufLM })^{*}\end{array}$ & + & - & - & - & - & + & - & + & - \\
\hline \multicolumn{10}{|l|}{ API $20 \mathrm{NE}^{\star}$} \\
\hline Nitrate reduction & + & + & - & + & - & - & - & - & + \\
\hline Arginine dihydrolase & + & + & $\mathrm{W}$ & - & - & - & + & $\mathrm{w}$ & - \\
\hline Urease & + & + & + & - & - & $\mathrm{w}$ & + & + & - \\
\hline \multicolumn{10}{|l|}{ API ZYM ${ }^{*}$} \\
\hline Esterase lipase (C8) & + & + & + & + & $\mathrm{W}$ & + & + & + & + \\
\hline Lipase (C14) & $\mathrm{w}$ & $\mathrm{W}$ & $\mathrm{w}$ & $\mathrm{w}$ & $\mathrm{w}$ & + & $\mathrm{w}$ & + & $\mathrm{w}$ \\
\hline Valine aminopeptidase & + & + & + & $\mathrm{W}$ & $\mathrm{w}$ & + & + & + & $\mathrm{W}$ \\
\hline Acid phosphatase & + & + & $\mathrm{w}$ & + & + & + & + & + & + \\
\hline Naphthol-AS-B1-phosphohydrolase & + & + & - & + & + & + & $\mathrm{w}$ & + & + \\
\hline Cystine aminopeptidase & - & - & - & - & - & - & - & $\mathrm{w}$ & - \\
\hline \multicolumn{10}{|l|}{ Susceptible to: } \\
\hline Ampicillin, chloromycetin & + & $-*$ & + & + & + & + & + & + & + \\
\hline Kanamycin & + & $+^{*}$ & - & + & + & + & + & + & + \\
\hline Streptomycin & - & $+^{*}$ & + & + & + & + & + & + & + \\
\hline DNA G $+C$ content $(\mathrm{mol} \%)$ & 63.6 & 59.0 & 62.3 & 58.6 & 66 & $63.3-63.4$ & 60.9 & $60.9-62.9$ & 59 \\
\hline
\end{tabular}

${ }^{\star}$ Results obtained in this study.

Whole-cell fatty acids from cells grown on MA 2216 medium at $28{ }^{\circ} \mathrm{C}$ for $48 \mathrm{~h}$ were extracted, saponified and esterified, followed by GC analysis of the fatty acid methyl esters according to the instructions of the MIDI system (Sasser, 1990). Type strains of eight species of the genus Roseovarius were tested under the same conditions in this study along with strain $\mathrm{B} 108^{\mathrm{T}}$. As shown in Supplementary Table S1, the major fatty acids of strain $\mathrm{B} 108^{\mathrm{T}}$ were $\mathrm{C}_{16: 0}$ (5.66\%), $\mathrm{C}_{16: 0} \quad 2-\mathrm{OH}(6.75 \%)$, summed feature 8 $\left(\mathrm{C}_{18: 1} \omega 7 c / \omega 6 c\right)(63.15 \%)$ and $\mathrm{C}_{19: 0} \omega 8 c$ cyclo $(8.64 \%)$, which accounted for $84.2 \%$ of the total cellular fatty acids. In addition, the major fatty acids of the other species of the genus Roseovarius tested were $\mathrm{C}_{16: 0}(5.66-17.63 \%)$ and summed feature $8 \quad\left(\mathrm{C}_{18: 1} \omega 7 c / \omega 6 c\right)(48.04-70.70 \%)$. The fatty acid profile of strain $\mathrm{B} 108^{\mathrm{T}}$ was in good agreement with those of members of the genus Roseovarius but could be differentiated from other species by the percentage of $\mathrm{C}_{16: 0}$ 2- $\mathrm{OH}$ and $\mathrm{C}_{19: 0} \omega 8 c$ cyclo.

Additionally, the genetic potential for anoxygenic phototrophy was determined by PCR amplification of the photosynthetic reaction centre genes ( $p u f L M$ ) using the primers pufLf (5'-CTKTTCGACTTCTGGGTSGG-3') and pufMr (5'-CCCATSGTCCAGCGCCAGAA-3') (Béjà et al., 2002). The specific $1.5 \mathrm{~kb}$ products were clearly amplified from strain $\mathrm{B} 108^{\mathrm{T}}$, R. tolerans $\mathrm{EL}-172^{\mathrm{T}}$ and R. mucosus DFL-24 ${ }^{\mathrm{T}}$, but not from the other six type strains tested. These results were similar to those of Oh et al. (2009), who only detected the specific PCR product in R. tolerans EL-172 ${ }^{\mathrm{T}}$ and $R$. mucosus DFL- $24^{\mathrm{T}}$ using the primers pufM.557F and pufM.750R.

The major respiratory quinone of strain $\mathrm{B}_{108^{\mathrm{T}}}$ was ubiquinone $10(\mathrm{Q} 10)$, as determined by HPLC using the 
method of Collins (1985). This trait was in accordance with the properties of members of the genus Roseovarius except that three type strains, $R$. pacificus $81-2^{\mathrm{T}}, R$. nubinhibens DSM $15170^{\mathrm{T}}$ and $R$. nanhaiticus $\mathrm{NH}^{2} \mathrm{~J}^{\mathrm{T}}$, have no available data. Polar lipids of strain $\mathrm{B} 108^{\mathrm{T}}$ were extracted and separated according to the methods described by Tindall (1990). The results are shown in Supplementary Fig. S2. The polar lipids of strain $\mathrm{B} 108^{\mathrm{T}}$ were phosphatidylcholine, phosphatidylglycerol, diphosphatidylglycerol, phosphatidylethanolamine and some unidentified compounds. These results were similar to the polar lipid patterns of $R$. halotolerans $\mathrm{HJ} 50^{\mathrm{T}}, R$. mucosus DFL- $24^{\mathrm{T}}$ and $R$. tolerans EL-172 ${ }^{\mathrm{T}}$.

On the basis of morphological, physiological and chemotaxonomic characteristics, together with data from $16 \mathrm{~S}$ rRNA gene sequence analysis and DNA-DNA hybridization tests described above, strain $\mathrm{B} 108^{\mathrm{T}}$ represents a novel species of the genus Roseovarius, for which the name Roseovarius indicus sp. nov. is proposed.

\section{Description of Roseovarius indicus sp. nov.}

Roseovarius indicus (in'di.cus. L. adj. indicus Indian, referring to the Indian Ocean, where the strain was isolated).

Cells are Gram-reaction-negative, non-motile, short rods, $1.7-2.4 \times 1.0-1.1 \mu \mathrm{m}$. Positive for catalase and oxidase activities and nitrate reduction, but negative for indole production, urease, lipase (Tween 80 ), gelatinase, $\beta$-glucosidase, $\beta$-galactosidase and arginine dihydrolase activities, glucose fermentation, denitrification and hydrolysis of aesculin. On $216 \mathrm{~L}$ agar, strain $\mathrm{B}_{108}{ }^{\mathrm{T}}$ produces smooth colonies with regular edges that are $2-3 \mathrm{~mm}$ in diameter after $72 \mathrm{~h}$ of incubation at $28{ }^{\circ} \mathrm{C}$. Colonies are opaque, white to faintly pink in the centre, non-pigmented and slightly raised in the centre. Moderately halophilic. Grows in $1-15 \%(\mathrm{w} / \mathrm{v}) \mathrm{NaCl}$ (optimum 3-5\%) and at 10 $39{ }^{\circ} \mathrm{C}$ (optimum $25{ }^{\circ} \mathrm{C}$ ), but not at 4 or $40{ }^{\circ} \mathrm{C}$ after 1 week. Principal fatty acids were $\mathrm{C}_{16: 0}, \mathrm{C}_{16: 0}$ 2-OH, summed feature $8\left(\mathrm{C}_{18: 1} \omega 7 c / \omega 6 c\right)$ and $\mathrm{C}_{19: 0} \omega 8 c$ cyclo. The major respiratory quinone was ubiquinone $10(\mathrm{Q} 10)$. Phosphatidylcholine, phosphatidylglycerol, diphosphatidylglycerol, phosphatidylethanolamine and some unidentified compounds were detected. The pufLM gene was detected. Sensitive to [ $\mu \mathrm{g}$ per disk (OXOID), unless stated otherwise]: ampicillin (10), carbenicillin (100), cefalexin (30), cefazolin (30), cefobid (30), cephradin (30), chloromycetin (30), ciprofloxacin (5), furazolidone (15), gentamicin (10), kanamycin (30), minomycin (30), norfloxacin (10), penicillin $G(10)$, piperacillin (100), rifampicin (5), rocephin (30), vancomycin (30); resistant to clindamycin (2), Cotrimoxazole (25), erythromycin (15), lincomycin (2), metronidazole (5), neomycin (10), ofloxacin (5), oxacillin (1), polymyxin B (30 IU), streptomycin (10), tetracycline (30) and vibramycin (30). In API ZYM tests: positive for acid phosphatase, alkaline phosphatase, esterase (C4), esterase lipase (C8), leucine aminopeptidase, naphthol-ASBl-phosphohydrolase and valine aminopeptidase; weakly positive for lipase (C14); negative for cystine aminopeptidase,
$N$-acetyl- $\beta$-glucosaminidase, trypsin, $\alpha$-chymotrypsin, $\alpha$ fucosidase, $\alpha$ - and $\beta$-galactosidase, $\alpha$ - and $\beta$-glucosidase, $\alpha$ mannosidase and $\beta$-glucuronidase. Negative for utilization of all 12 carbon sources in API 20 NE tests. Characteristics used to distinguish strain $\mathrm{B} 108^{\mathrm{T}}$ from related species are shown in Table 1.

The type strain, $\mathrm{B} 108^{\mathrm{T}} \quad\left(=2 \mathrm{PR} 52-14^{\mathrm{T}}=\right.$ CCTCC $\mathrm{AB}$ $208233^{\mathrm{T}}=$ LMG $24622^{\mathrm{T}}=$ MCCC $1 \mathrm{~A} 01227^{\mathrm{T}}$ ), was isolated from deep-sea water of the Indian Ocean. The DNA G + C content of the type strain is $63.6 \mathrm{~mol} \%$.

\section{Acknowledgements}

Q. L. is a PhD student of Xiamen University, co-supervised by T.Z. and Z.S.; all work was done at the Third Institute of Oceanography, State Oceanic Administration, Xiamen, PR China. This work was financially supported by the National Infrastructure of Natural Resources for Science and Technology Program of China (no. 2005DKA21209), the National Natural Science Foundation of China (no. 40906083) and the Scientific Research Foundation of Third Institute of Oceanography, State Oceanic Administration (no. 2009065).

\section{References}

Ausubel, F. M., Brent, R., Kingston, R. E., Moore, D. D., Seidman, J. G., Smith, J. A. \& Struhl, K. (editors) (1995). Short Protocols in Molecular Biology: a Compendium of Methods from Current Protocols in Molecular Biology, 3rd edn. New York: Wiley.

Béjà, O., Suzuki, M. T., Heidelberg, J. F., Nelson, W. C., Preston, C. M., Hamada, T., Eisen, J. A., Fraser, C. M. \& DeLong, E. F. (2002). Unsuspected diversity among marine aerobic anoxygenic phototrophs. Nature 415, 630-633.

Biebl, H., Allgaier, M., Lünsdorf, H., Pukall, R., Tindall, B. J. \& Wagner-Döbler, I. (2005). Roseovarius mucosus sp. nov., a member of the Roseobacter clade with trace amounts of bacteriochlorophyll $a$. Int J Syst Evol Microbiol 55, 2377-2383.

Boettcher, K. J., Geaghan, K. K., Maloy, A. P. \& Barber, B. J. (2005). Roseovarius crassostreae sp. nov., a member of the Roseobacter clade and the apparent cause of juvenile oyster disease (JOD) in cultured Eastern oysters. Int J Syst Evol Microbiol 55, 1531-1537.

Collins, M. D. (1985). Isoprenoid quinone analysis in bacterial classification and identification. In Chemical Methods in Bacterial Systematics, pp. 267-287. Edited by M. Goodfellow \& D. E. Minnikin. London: Academic Press.

González, J. M., Covert, J. S., Whitman, W. B., Henriksen, J. R., Mayer, F., Scharf, B., Schmitt, R., Buchan, A., Fuhrman, J. A. \& other authors (2003). Silicibacter pomeroyi sp. nov. and Roseovarius nubinhibens sp. nov., dimethylsulfoniopropionate-demethylating bacteria from marine environments. Int J Syst Evol Microbiol 53, 1261-1269.

Labrenz, M., Collins, M. D., Lawson, P. A., Tindall, B. J., Schumann, P. \& Hirsch, P. (1999). Roseovarius tolerans gen. nov., sp. nov., a budding bacterium with variable bacteriochlorophyll a production from hypersaline Ekho Lake. Int J Syst Bacteriol 49, 137-147.

Lai, Q., Qiao, N., Wu, C., Sun, F., Yuan, J. \& Shao, Z. (2010). Stappia indica sp. nov., isolated from deep seawater of the Indian Ocean. Int $J$ Syst Evol Microbiol 60, 733-736.

Liu, C. L. \& Shao, Z. Z. (2005). Alcanivorax dieselolei sp. nov., a novel alkane-degrading bacterium isolated from sea water and deep-sea sediment. Int J Syst Evol Microbiol 55, 1181-1186. 
Mesbah, M. \& Whitman, W. B. (1989). Measurement of deoxyguanosine/thymidine ratios in complex mixtures by high-performance liquid chromatography for determination of the mole percentage guanine + cytosine of DNA. J Chromatogr A 479, 297-306.

Oh, Y. S., Lim, H. J., Cha, I. T., Im, W. T., Yoo, J. S., Kang, U. G., Rhee, S. K. \& Roh, D. H. (2009). Roseovarius halotolerans sp. nov., isolated from deep seawater. Int J Syst Evol Microbiol 59, 2718-2723.

Rzhetsky, A. \& Nei, M. (1992). A simple method for estimating and testing minimum-evolution trees. Mol Biol Evol 9, 945-967.

Rzhetsky, A. \& Nei, M. (1993). Theoretical foundation of the minimum-evolution method of phylogenetic inference. Mol Biol Evol 10, 1073-1095.

Saitou, N. \& Nei, M. (1987). The neighbor-joining method: a new method for reconstructing phylogenetic trees. Mol Biol Evol 4, 406-425.

Sasser, M. (1990). Identification of bacteria by gas chromatography of cellular fatty acids. MIDI Technical Note 101. Newark, DE: MIDI Inc.

Stackebrandt, E. \& Goebel, B. M. (1994). Taxonomic note: a place for DNA-DNA reassociation and $16 \mathrm{~S}$ rRNA sequence analysis in the present species definition in bacteriology. Int J Syst Bacteriol 44, 846-849.
Tamura, K., Dudley, J., Nei, M. \& Kumar, S. (2007). MEGA4: molecular evolutionary genetics analysis (MEGA) software version 4.0. Mol Biol Evol 24, 1596-1599.

Tindall, B. J. (1990). Lipid composition of Halobacterium lacusprofundi. FEMS Microbiol Lett 66, 199-202.

Wang, B., Tan, T. \& Shao, Z. (2009). Roseovarius pacificus sp. nov., isolated from deep-sea sediment. Int J Syst Evol Microbiol 59, 11161121.

Wang, B., Sun, F., Lai, O., Du, Y., Liu, X., Li, G., Luo, J. \& Shao, Z. (2010). Roseovarius nanhaiticus sp. nov., a member of the Roseobacter clade isolated from marine sediment. Int J Syst Evol Microbiol 60, 1289-1295.

Wayne, L. G., Brenner, D. J., Colwell, R. R., Grimont, P. A. D., Kandler, O., Krichevsky, M. I., Moore, L. H., Moore, W. E. C., Murray, R. G. E. \& other authors (1987). Report of the ad hoc committee on reconciliation of approaches to bacterial systematics. Int J Syst Bacteriol 37, 463-464.

Yoon, J.-H., Kang, S.-J. \& Oh, T.-K. (2008). Roseovarius aestuarii sp. nov., isolated from a tidal flat of the Yellow Sea in Korea. Int J Syst Evol Microbiol 58, 1198-1202. 